\title{
Eco-Friendly Management of Brinjal Shoot and Fruit Borer (Leucinodes orbonalis Guenee) in Allahabad, India
}

\author{
Paylet Kumar Sahu', Ashwani Kumar ${ }^{1}$ and Pradeep Kumar Kujur ${ }^{2 *}$ \\ ${ }^{1}$ Department of Entomology, Sam Higginbottom Institute of Agriculture, \\ Technology and Sciences, Allahabad, U.P., India \\ ${ }^{2}$ Department of Horticulture, Sam Higginbottom Institute of Agriculture, Technology and \\ Sciences, Allahabad, U.P., India \\ *Corresponding author
}

\section{A B S T R A C T}

\begin{tabular}{|l|}
\hline Ke y w o r d s \\
Brinjal, Infestation, \\
Brinjal shoot and \\
fruit borer \\
(Leucinodes \\
orbonalis), and \\
Treatments.
\end{tabular}

A field experiment was conducted during Kharif, 2014 at the central research farm of Sam Higginbottom Institute of Agriculture Technology and Sciences, Allahabad to evaluate the Eco-friendly management of Brinjal shoot and fruit borer [Leucinodes orbonalis (Guenee)]. The per cent infestation of brinjal shoot and fruit borer (L. orbonalis) on seventh and fourteenth days after spraying revealed that all treatments are superior over control. Among the treatments Chlorpyriphos $20 \mathrm{EC}$ found superior over all the treatments followed by Chlorpyriphos + Neem oil and Chlorpyriphos + NSKE after first, second and third sprays respectively. Among the neem products neem oil found superior over other Neem products. Minimum per cent infestation (10.05\%) and highest yield of (350 q/ha.) were recorded in Chlorpyriphos @ 3ml/ lit. followed by Chloropyrifos+ Neem oil, Chlorpyriphos + NSKE, neem oil, NSKE, Beauria bassiana, Bacillus thuringiensis as compared to untreated.

\section{Introduction}

The eggplant or aubergine or brinjal (Solanum melongena $\mathrm{L}$.) is one of the most important solanaceous vegetables in south-east Asian countries including India, brinjal is indigenous vegetable crop often known as the cash crop for the farmers. It is an important vegetable grown in all the seasons. Due to its nutritive value, consisting of minerals like iron, phosphorous, calcium and vitamins like A, B and C, unripe fruits are used primarily as vegetable in the country. Brinjal belongs to the family Solanaceae $2 n=24$. This important crop is subjected to attack by many insect pests throughout its growth period which act as limiting factor in its profitable cultivation. The important insect pests are shoot and fruit borer [Leucinodes orbonalis (Guenee)], Lacewing bug (Urentius sentis Distant), Hadda beetle (Epilachna vigintioctopunctata Fabricius), Jassid (Amarasca bigutulla bigutulla Ishida), brinjal stem borer (Euzophera perticella Rag.), and White Fly, Bemisia tabaci (Genn.), While its minor pests include aphid (Aphis gossypii Glover), brinjal leaf roller (Eublemma olivacea Walker), jassid (Hishimonas phycitis) etc. (Atwal and Dhaliwal, 2005). Brinjal shoot and fruit borer [Leucinodes orbonalis (Guenee)] is 
considered to be the most destructive pest of brinjal in all part of India (Mote, 1976), (Wargantiwar et al., 2010). Studied bioefficacy of some botanical and their combination with chemicals and (Yogi and Kumar 2010) evaluated some chemical insecticides against (Leucinodes orbonalis) from Allahabad. The shoot and fruit borer is the most severe pest of brinjal. The larvae bore into tender shoots resulting the withering of infested shoots and tender leaves. At the letter stage the crop growth, the caterpillars bore into flower buds and fruits. The affected flower buds are shed while fruits become unfit for human consumption. Crop losses have been reported to the tune of 13.30 to 88.70 per cent in various parts of the country by this pest.

\section{Materials and Methods}

The field trial was conducted during the kharif season from July to December 2014 the variety Banarasi Round -1 was sown in the Research farm of SHIATS Allahabad using RBD in three replication having plot size $2 \times 2$ $\mathrm{m}^{2}$. Seven treatments comprising of neem oil $2 \%\left(\mathrm{~T}_{1}\right)$, NSKE (T2), Beauveria bessiana $10 \%$ (T3), Bacillus thuringensis 85 (T4), Chloropyrifos 20\% EC (T5), Chloropyrifos + Neem oil (T6), Chloropyrifos + NSKE (T7) were used to check their efficacy against (Leucinodes orbonalis) on Brinjal. The first spray of respective insecticides was made on appearance of (Leucinodes orbonalis), subsequent three sprays were given at 15 days interval.

The insecticides were evaluated on the basis of per cent shoot damage, per cent fruit damage as well as brinjal fruit yield and cost benefit ratio. For recording observations on shoot damage and fruit damage infestation, five plants were selected randomly in each plot and observations on percent infestation were recorded from the same selected plants. Shoot damage was recorded by counting total and damaged shoots from the each plot. The observations on fruit damage were made by counting total and damaged fruits from each plot at each picking. The observations on shoot damage and fruit damage were made before 24 hours of first spray as well as 7 and 14 days after each spray. Fruit yield was recorded picking wise. Second and third spray was given for preventing fruit damage.

The data regarding the fruit yield from each picking of each plot were recorded carefully and added to get the total yield of each plot.

\section{Results and Discussion}

The data on effect of insecticides on per cent shoot damage caused by Leucinodes orbonalis are presented in Table 1. The data indicated that there was uniform shoot damage in the field before the first spray as the treatment differences were nonsignificant. The data also revealed that all the insecticidal treatments were significantly effective when compared with control after 7 and 14 days of spray. The data on the percent infestation of shoot and fruit borer on seventh day \& fourteenth day after spray revealed that, all the treatments were significantly superior over control.

Among all the treatments lowest percent infestation of shoot was recorded in chlorpyriphos (10.43\%) followed by chlorpyriphos + neem oil (12.42\%), chlorpyriphos + NSKE (12.81\%), neem oil (13.33\%), NSKE (14.99\%), Beauveria bassiana (15.22\%), Bacillus thuringensis (15.55\%). Bacillus thuringensis (15.55\%) was least effective among all the treatments. Treatments Bacillus thuringensis, Beauveria bassiana and NSKE were non-significant and statistically at par with each other and also treatments neem oil, chlorpyriphos + NSKE and chlorpyriphos + neem oil were nonsignificant and statistically at par with each other. 
Table.1 Field evaluation on eco- friendly management of brinjal shoot and fruit borer (Leucinodes orbonalis) in Allahabad

\begin{tabular}{|c|c|c|c|c|c|c|c|c|c|}
\hline & Shoot Infe & on $(\%)$ & & & Fruit Infes & on $(\%)$ & & & \\
\hline & & $1^{\text {st }} \mathrm{sp}$ & DAS & & $2^{\text {nd }} \mathrm{sp}$ & DAS & & $3^{\text {rd }} \mathrm{sr}$ & DAS \\
\hline Treatments Dose & Before & 7 & 14 & Before & 7 & 14 & Before & 7 & 14 \\
\hline & 20.89 & 21.12 & 23.43 & 21.92 & 22.43 & 23.85 & 23.02 & 29.05 & 29.82 \\
\hline water spray & $(27.19)^{*}$ & $(27.35)^{*}$ & $(28.94)^{*}$ & $(27.91)^{*}$ & $(28.26)^{*}$ & $(29.23)^{*}$ & $(28.67)^{*}$ & $(32.61)^{*}$ & $(33.09)^{*}$ \\
\hline Neem Oil 2\% & 22.37 & -12.91 & 13.76 & 14.4 & 13.09 & 14.15 & 14.37 & 13.72 & 13.44 \\
\hline Neem Uil $2 \%$ & $(28.22)^{*}$ & $(21.05)^{*}$ & $(21.77)^{*}$ & $(22.30)^{*}$ & $(21.21)^{*}$ & $(22.09)^{*}$ & $(22.27)^{*}$ & $(21.74)^{*}$ & $(21.50)^{*}$ \\
\hline NCVE 50 & 20.1 & 14.91 & 15.08 & 20.63 & 13.71 & 15.05 & 17.19 & 15.14 & 14.04 \\
\hline NSRE $5 \%$ & $(26.63)^{*}$ & $(22.71)^{*}$ & $(22.85)^{*}$ & $(27.01)^{*}$ & $(21.73)^{*}$ & $(22.82)^{*}$ & $(24.49)^{*}$ & $(22.89)^{*}$ & $(22.00)^{*}$ \\
\hline Beauveria bassiana $10 \%$ & 16.48 & 14.56 & 15.89 & 17.4 & 14.68 & 14.95 & 18.01 & 14.33 & 14.3 \\
\hline WP & $(23.95)^{*}$ & $(22.43)^{*}$ & $(23.49)^{*}$ & $(24.65)^{*}$ & $(22.52)^{*}$ & $(22.74)^{*}$ & $(25.11)^{*}$ & $(22.24)^{*}$ & $(22.21)^{*}$ \\
\hline Bacillus thuringensis 85 & 20.82 & 15.04 & 16.07 & 21.91 & 16.74 & 16.54 & 21.88 & 15.33 & 14.28 \\
\hline WG & $(27.14)^{*}$ & $(22.81)^{*}$ & $(23.63)^{*}$ & $(27.90)^{*}$ & $(24.15)^{*}$ & $(23.99)^{*}$ & $(27.88)^{*}$ & $(23.05)^{*}$ & $(22.20)^{*}$ \\
\hline Chloromurifos $200 \mathrm{EC}$ & 19.56 & 10.09 & 10.78 & 22.92 & 9.75 & 10.8 & 22.57 & 9.09 & 10.57 \\
\hline CnIoropyrilos $20 \% \mathrm{EC}$ & $(26.24)^{*}$ & $(18.52)^{*}$ & $(19.16)^{*}$ & $(28.60)^{*}$ & $(18.19)^{*}$ & $(19.18)^{*}$ & $(28.34)^{*}$ & $(17.54)^{*}$ & $(18.97)^{*}$ \\
\hline Chlommunifor Nom il & 18.56 & 12.05 & 12.79 & 18.56 & 11.47 & 12.17 & 22.89 & 11.23 & 12.07 \\
\hline Cnioropyrilos+ Neem oil & $(25.51)^{*}$ & $(20.31)^{*}$ & $(20.95)^{*}$ & $(25.51)^{*}$ & $(19.79)^{*}$ & $(20.41)^{*}$ & $(28.58)^{*}$ & $(19.57)^{*}$ & $(20.32)^{*}$ \\
\hline & 20.42 & 12.1 & 13.52 & 25.41 & 12.14 & 13.81 & 22.03 & 12.13 & 12.49 \\
\hline CnIoropyriIos + NSKE & $(26.86)^{*}$ & $(20.35)^{*}$ & $(21.57)^{*}$ & $(30.27)^{*}$ & $(20.39)^{*}$ & $(21.81)^{*}$ & $(27.99)^{*}$ & $(20.38)^{*}$ & $(20.69)^{*}$ \\
\hline Overall Mean & 19.9 & 14.09 & 15.16 & 20.39 & 14.25 & 15.16 & 19.76 & 15 & 15.12 \\
\hline F- test & NS & $\mathbf{S}$ & $\mathbf{S}$ & NS & $\mathbf{S}$ & $\mathbf{S}$ & NS & $\mathbf{S}$ & $\mathbf{S}$ \\
\hline S. Ed. ( $( \pm)$ & 2.09 & 0.72 & 0.43 & 3.88 & 0.92 & 0.57 & 4.09 & 0.31 & 0.35 \\
\hline C. D. $(P=0.05)$ & 4.47 & 1.55 & 0.93 & 8.32 & 1.98 & 1.23 & 8.77 & 0.67 & 0.74 \\
\hline
\end{tabular}


The data on the percent infestation of shoot and fruit borer on second and third spray overall mean revealed that all the treatments were significantly superior over control. Among all the treatments lowest percent infestation of fruit was recorded in chlorpyriphos $(10.05 \%)$ followed by chlorpyriphos + neem oil (11.73\%), chlorpyriphos + NSKE (12.51\%), neem oil (13.60\%), NSKE (14.48\%), Beauveria bassiana (14.56\%) and Bacillus thuringiensis (15.72\%). Bacillus thuringiensis (15.72\%) was least effective among all the treatments. Treatments Bacillus thurengiensis and Beauveria bassiana were non-significant and statistically at par with each other and also Treatments Beauveria bassiana, NSKE, neem oil, chlorpyriphos + NSKE, chlorpyriphos + neem oil and chlorpyriphos were non-significant and statistically at par with each other.

The probable reason for such findings may be that chlorpyriphos killed the pest by paralyzing them at a faster rate and as such the fruit infestation was found to be minimum. Since, the insect population was minimum as such the plants were healthy and gave higher number of fruits. This treatment recorded maximum return and higher cost benefit ratio. Nenavati and Kumar (2014) reported chlorpyriphos was most effective in the reduction of damage of shoot and fruit infestation. However, shoot and fruit infestation was brought down and marketable yield increased to some extent, when the chlorpyriphos combined with other insecticides. The results revealed that chlorpyriphos was found to be most economical, resulting in minimum shoot and fruit infestation Sharma et al., (2012). Among botanicals the highest reduction of brinjal shoot and fruit borer infestation was found in the plots treated by neem oil and it was most effective and these results were supported by Rahman et al., (2009). Bacillus thurengiensis resulted maximum shoot and fruit infestation, less effective and more expensive controlling the pest. The results are supported by Mathur and
Jain (2009).

\section{References}

Atwal, A. S., and Dhaliwal, G. S. 2005. Indian Agricultural pests of South Asia and their management. Kalyani publishers, 4(2): 172-174.

Khan, A. S., and Lyall, H. 2013. Efficacy of chemical and plant products in management of Earias vittella (Fab.) Ann.pl. protcec. Science, 21(2)283-285

Mathur, A., and Jain, N. 2009. Control of shoot and fruit borer of brinjal (Leucinodes orbonalis) in field. Entomon, 31(2): 141144.

Mote, U.N., 1976. Seasonal incidence and chemical control of brinjal shoot and fruit borer Leucinodes orbonalis, (Guen). Vegetable Science, 3(2): 128-310.

Nenavati, R.N., and Kumar, A. 2014. Efficacy of certain insecticides against seasonal incidence of shoot and fruit borer, Earias vittella Fabricius on okra. Annals of Plant Protection Sciences, 22(1): 95-97.

Rahman, M. M., Islam, K. S., Jahan, M. and Uddin M.A. 2009. Efficacy of some botanicals in controlling brinjal shoot and fruit borer, Leucinodes orbonalis. Progress. Agric., 20(1 \& 2): 35-42.

Sharma, D.K., Masarrat, H. Muntaha Q. 2012. Comparative potential of different botanical and synthetic incecticides and their economics against Leucinodes orbonalis. Eggplant. Journal of Plant Protection Research, 52 (1):36:38.

Wargantiwar, R. K., Kumar A. and Kumar, S. 2010. Bioefficacy of some botanicals and in combination with insecticide against Leucinodes orbonalis (Guenee) in brinjal under Allahabad agro-climatic condition International Journal of Plant Protection, 3(2): 245-247.

Yogi, K., and Kumar, A. 2010. Labarotory evaluation of inscectides on brinjal shoot and fruit borer, Leucinodes orbonalis (Guenee) Pestology $x x x$, IV (7): 58-63. 
How to cite this article:

Paylet Kumar Sahu, Ashwani Kumar and Pradeep Kumar Kujur. 2017. Eco-Friendly Management of Brinjal Shoot and Fruit Borer (Leucinodes orbonalis Guenee) in Allahabad. Int.J.Curr.Microbiol.App.Sci. 6(10): 2814-2818. doi: https://doi.org/10.20546/ijcmas.2017.610.329 